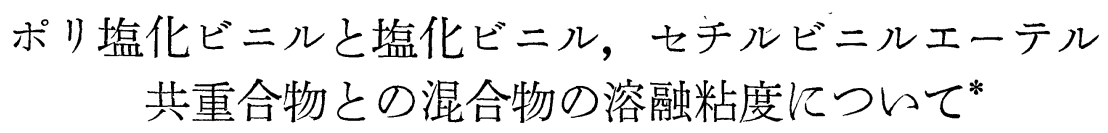

星勇 二**

\title{
The Melt Viscosity of Blends of Polyvinyl Chloride and a Copolymer of Vinyl Chloride and Cetyl Vinyl Ether
}

by

\author{
Yuji HosHI \\ (Kureha Chemical Ind. Co., Ltd., Tokyo)
}

The melt flow characteristics of blends of PVC and a copolymer of vinyl chloride and cetyl vinyl either were measured by means of a flow tester, and compared with those of PVC homopolymer, lightly plasticized PVC and other rigid PVC compositions.

The apparent melt viscosity $\eta_{a}$ of the blends was less dependent on temperature, in contrast to other polymers. In the blends containing 25 to $75 \%$ of copolymer, there was no change in flow activation energy.

The results of microscopic observation and dynamic loss measurement of the fabricated products showed that the blends had rather two-phase structure than perfectly compatible phase.

From these results, it was considered that the copolymer in the blends covered the surface of flow unit of compatible mix of PVC and the copolymer in the course of processing.

(Received Jan. 19, 1970)

\section{1 緒言}

ポリ塩化ビニル（PVC）の透明性を生かした硬質 PVC 製品の新しい発展を期待して, PVC の改質研究 の過程で見いだされた塩化ビニルー高級アルキルビニ ルエーテル共重合物は，これをPVC と混合すること によって, 硬質 PVC 製品用として加工性の改良効果 をるたらすことが著者らによって知られた。本研究は この共重合物が加工改質剤として寄与する効果を, 加 エに関連する諸条件で評価することを目的とした。す なわち従来 PVC 樹脂の品質評価が JIS, ASTM な ぞによる物理的性質の測定の反限定され，加工にお いては経験的評価にたよっていたのにかんがみ，本研 究では原料樹脂の加工工程之関連させた意味づけと, それによる硬質 PVC 製品への利用とその開発を目的 とした。

塩化ビニルとアルキルビニルェーテルとの共重合物 は初期にブチルビニルェーテルが試みられ，その後赤 染らによって長鎖アルキルビニルェーテルと塩化ビニ

* 本報を「硬質ポリ塩化ビニルの加工および材料物性に関する研究 (第 1 報)」 (Research on the Processing and Materials Properties of Rigid Polyvinyl Chloride, I) とする. 原稿受理 昭和 45 年 1 月 19 日

** 正 会員 呉羽化学工業 (株) 東京都中央区日本橋堀留町
ルとの共重合物の研究が行なわれ，軟質のPVC 製品 を対象としてその実用性が検討された。本研究は，ア ルキル長鎖を共重合させた内部可塑化による軟質化を 企図した従来の研究と異なり, 硬質 PVC 分野にこの 樹脂の利用を図ることを目的としたものである。本報 は各樹脂の溶融粘度から反た加工特性について述べる。

PVC の加工に扔いて，加工機の溶融域に打梳る樹 脂の粘度は, 加工性, 樹脂温度の上昇および熱分解を きめる特性である。硬質 PVC 用の単独重合物として は, 工業的加工性子最終製品江要求される物理的性質 艺满足させるといら観点から, 原料樹脂として平均重 合度 $700 \sim 800$ の PVC が使用されているが, これら は広い種類の加工機, 加工条件飞抢いての易加工性 PVC とはい光ず，場合により熱分解，着色を叔こし やすい, 本報では, 高化式フローテスターによって測 定された溶融粘度の特徵を著者らの混合組成物, 単独 PVC 打よび他の硬質用の塩ビ系共重合物について比 較し,われわれの組成物の加工性の特徵を追求するこ とを目的とした。

\section{2 実 験 方 法}

\section{$2 \cdot 1$ 試料}

*1 JIS K 6721 の表示による. 
（1）塩化ビニルーアルキルビニルエーテル共重合物 $\mathrm{PVC}$ との混合に使用された共重合物〔以下 $\mathrm{P}(\mathrm{VC}-$ $\mathrm{VE})$ と略記する]で, 塩化ビニル (以下 VC) と, セチルビニルェーテルとを 9:1 の単量体仕込比で重 合率 $88 \%$ まで㜀濁重合させたのち，モノマーを追い出 し，乾燥させたものである。一般性状は次のと和りで ある。

性状

平均重合度 480

見かけ比重 $0.47 \mathrm{~g} / \mathrm{cm}^{3}$

粒度分布 150 メッツュピーク

$\mathrm{P}(\mathrm{VC}-\mathrm{VE})$ は $2 \%$ のチルビニルエーテル和よびセ チルアルコールを含み，共重合物はカリウス法により， 91\% VC，9\%七チルビニルエーテルより成ることが わかった。な执セチルビニルェーテルは抹香油をけん 化して得られた高級アルコールを $\mathrm{KOH}$ を触媒として アセチレンと反応させビニル化したものである．組成 分布は C 16 成分 $70 \% ， \mathrm{C} 14$ 抒よび C 18 成分それぞ れ15\%である。

(2) PVC

平均重合度 600,700 および 800 の懸濁重合物を用 いた

（3）その他塩ビ系共重合物

(a) 塩化ビニル一酢酸ビニル共重合物

$5 \%$ 酶酸ビニルを含む共重合物〔以下 $\mathrm{P}(\mathrm{VC}-\mathrm{VAC})$ と略記する]で平均重合度 700 のもを用いた。

(b) 塩化ビニループロピレン共重合物

プロピレン $3 \%$ を含む共重合物〔以下 $\mathrm{P}(\mathrm{VC}-\mathrm{PP})$ と略記する]で平均重合度 700. US カンバランド社 製品.

(4) 添加剤

(a) 安定剂 ジブチルスズビスブチルマレート を使用した。日東化成（株）製 N2000E。

(b) $\mathrm{DOP}$

フタール酸ジオクチル（2エチルヘキシル）

\section{$2 \cdot 2$ 実験方法}

(1) 測定機

高化式フローテスターを用い，ノズルから流出する 試料の流動速度を所定のノズル, 圧力, 温度で求めた。

(2) 試料調製

各樹脂 100 部につき安定剤を 2 部添加し, ヘンシェ ルブレンダーで混合した後 $150^{\circ} \mathrm{C} て ゙ ， 3$ 分間ロール混 練を行なったシートをチップ飞切断して試料とした。

(3) 測定条件

各樹脂の溶融粘度と温度との関係を求める実験は, 荷重 $150 \mathrm{~kg} / \mathrm{m}^{2}$ ，ノズル $1 \mathrm{~mm} \times 10 \mathrm{~mm}$ を用い, 温 度 $160^{\circ} \mathrm{C}$ から $210^{\circ} \mathrm{C}$ でで行なった。また PVCと PVC $+\mathrm{P}(\mathrm{VC}-\mathrm{VE}) 25 \%$ については，5種のノズルを用い，
各ノズルにつき $20 〜 515 \mathrm{~kg} / \mathrm{cm}^{2}$ の範囲で10種の異な る圧力下で測定を行ない，せ九断速度，せ九断応力の 関係を求めた。

(4) 測定值の整理

樹脂の見かけせ几断応力 $\tau_{\omega}^{\prime}$ と見か汗せん断速度 $D_{\omega}^{\prime}$ とを, 次の式によって求めた。

$$
\begin{gathered}
\tau_{\omega}{ }^{\prime}=P R / 2 L \\
D_{\omega}{ }^{\prime}=4 Q / \pi R^{3}
\end{gathered}
$$

ここで $P$ は管端の圧力差， $Q$ は流出速度， $R$ 㧊よび $L$ はそれぞれ毛細管の半径と長さである. Bagley の方 式によって，管長補正を行ない， $D_{\omega}^{\prime}$ とせん断応力 $\tau_{\omega}$ との関係に整理した。

\section{3 実 験 結 果}

\section{$3 \cdot 1$ 各樹脂の見かけ溶解粘度と温度との関係}

樹脂の円管流動に括いては，実際の押出機における ような三次元的な混練が行なわれないので，両者に特 ける溶融粘度の值は必ずしも一致しないが，円管流動 で求めた溶融粘度は成型加工に和沪る溶融挙動の有力 な目安になる。ここでは 3 種の PVC，共重合物拈よ び $\mathrm{PVC}+\mathrm{P}(\mathrm{VC}-\mathrm{VE})$ そついて, 見かけ溶融粘度 $\eta$ と温度との関係を調べた。実験は $160^{\circ} \mathrm{C} \sim 210^{\circ} \mathrm{C} て ゙ 一$ 定 ノズル，一定荷重で行ない，流出速度から $\eta_{a}$ を求め た. 7 種の樹脂についての結果をFig. 1 飞まとめた.

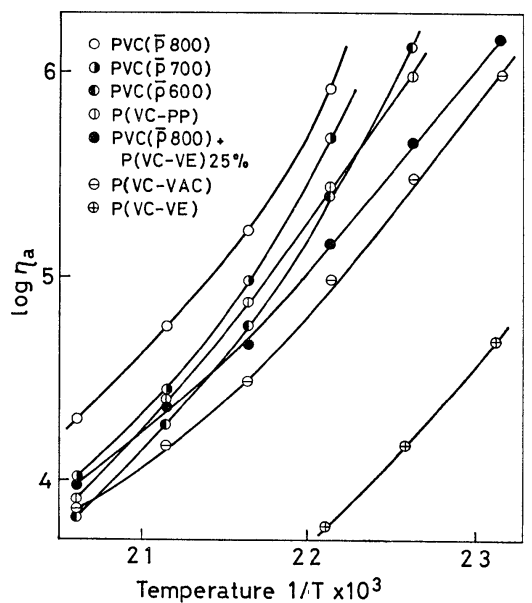

F1g. 1. A comparison of temperature dependences of $\eta_{a}$ of a blend and other polymers.

この図に招いて， $\bar{p}=600,700,800$ の単独 PVC の $\eta_{a} \sim 1 / T$ 曲線の傾斜には大きな差はないが， PVC $+\mathrm{P}(\mathrm{VC}-\mathrm{VE}) 25 \%$ の曲線は高温側で PVC $\bar{p} 700$ に 近いにかかわらず， $160^{\circ} \mathrm{C} \sim 170^{\circ} \mathrm{C} て ゙ は \mathrm{PVC}$ 五 600 よ り低い. $\log \eta_{a}=\log A+E_{a} / 2.303 R T$ として, $180^{\circ} \mathrm{C}$ ～200"C に和沙る曲線の傾斜から見かけの流動活性化 エネルギ $E_{a}$ を求めると, Table I のようになり， 3 種の PVC に比へ $\mathrm{PVC}+\mathrm{P}(\mathrm{VC}-\mathrm{VE})$ は低い值を示 
している.

一般に硬質 PVC の成型汹括ける樹脂の溶出温度は $200^{\circ} \mathrm{C}$ 近辺であるが，供給樹脂が常温から溶出温度に 至るまでの溶融特性が加工性を意味づける点から, 低 温度域で粘性が低いことは, 負荷の軽減, 摩擦熱の低 減などと関連して易加工性の条件であるとい光る。

\section{$3 \cdot 2$ PVC と P (VC-VE) の混合組成率と溶融粘 度との関係}

Fig. 2 は PVC $\bar{p} 800$ と $\mathrm{P}(\mathrm{VC}-\mathrm{VE})$ との混合組成 比が変化することによって $\eta_{a}$ と温度との関係がいか に変化するかを示した図である。 $\eta_{a}$ の温度依存性を みると，PVCに $\mathrm{P}(\mathrm{VC}-\mathrm{VE})$ を添加する割合が多く なるにつれて直線の傾斜がゆるやかになっているが， $\mathrm{P}(\mathrm{VC}-\mathrm{VE})$ の含有量 $20 \sim 75 \%$ までは直線の傾斜が洼 とんぞ同じで, 含有量 100\% になって初めて傾斜が変 わっている。この関係を見か汁の流動活性化エネルギ $E_{a}$ でみると，Table I のようになる。すなわち， PVC に DOP の上万な相溶性のよい可塑剤を添加す

Table I. Apparent activation energy.

\begin{tabular}{|c|c|c|}
\hline$F_{1 g}$ & Polymer & $\begin{array}{c}E_{a}, \\
\text { (Kcal/Mole) }\end{array}$ \\
\hline \multirow[t]{7}{*}{ Fig 1} & $\operatorname{PVC}(\bar{p} 800)$ & 58 \\
\hline & $\operatorname{PVC}(\bar{p} 700)$ & 62 \\
\hline & $\operatorname{PVC}(\bar{p} 600)$ & 55 \\
\hline & $\operatorname{PVC}(\bar{p} 800)+\mathrm{P}(\mathrm{VC}-\mathrm{VE}) 25 \%$ & 42 \\
\hline & $P(V C-V A C)$ & 42 \\
\hline & $\mathrm{P}(\mathrm{VC}-\mathrm{PP})$ & 51 \\
\hline & $\mathrm{P}(\mathrm{VC}-\mathrm{VE})$ & 33 \\
\hline \multirow[t]{4}{*}{$F_{1 g} 2$} & $\mathrm{PVC}+\mathrm{P}(\mathrm{VC}-\mathrm{VE}) 10 \%$ & 54 \\
\hline & $\mathrm{PVC}+\mathrm{P}(\mathrm{VC}-\mathrm{VE}) 20 \%$ & 45 \\
\hline & $\mathrm{PVC}+\mathrm{P}(\mathrm{VC}-\mathrm{VE}) 50 \%$ & 42 \\
\hline & $\mathrm{PVC}+\mathrm{P}(\mathrm{VC}-\mathrm{VE}) 75 \%$ & 43 \\
\hline
\end{tabular}

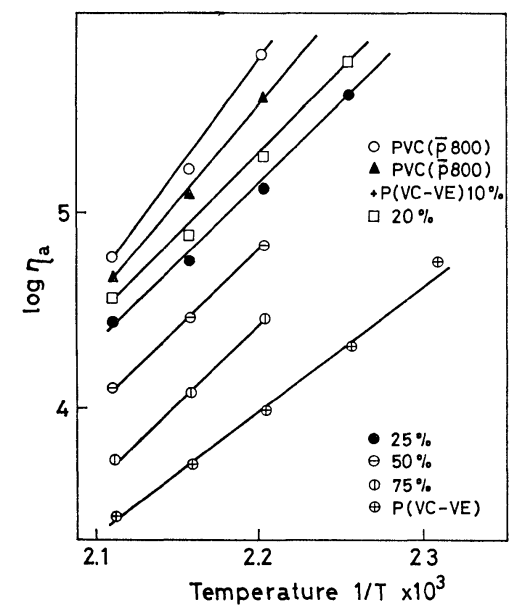

Fig. 2. Temperature dependence of $\eta_{a}$ of another blend.
る場合には, 添加量が増すに従って活性化ェネルギは 低下することが知られているが，P(VC-VE) の場合 はこれと異なる流動挙動をとっている。このことにつ いては粘弾性吸収による分散状態の考察として後述す る。

\section{$3 \cdot 3$ 可塑化 PVC との比較}

Fig. 3 は, 少量の DOP を含吉 PVC 組成物と PV $\mathrm{C}+\mathrm{P}(\mathrm{VC}-\mathrm{VE})$ 混合組成物の $\eta_{a}$ の温度依存性を示し たものである。この四からも， $\mathrm{PVC}+\mathrm{P}(\mathrm{VC}-\mathrm{VE})$ は $\mathrm{PVC}+\mathrm{DOP}$ とは異なる温度依存性を示して和り, 高 温側では同程度の $\eta_{a}$ を示すが, $160^{\circ} \mathrm{C} \sim 170^{\circ} \mathrm{C}$ の低温 側では低い $\eta_{a}$ を示している.P (VC-VE) は PVC に 対し親和性, 溶解性の良好な可塑剤と異なる混合性を 示すものと推察される。

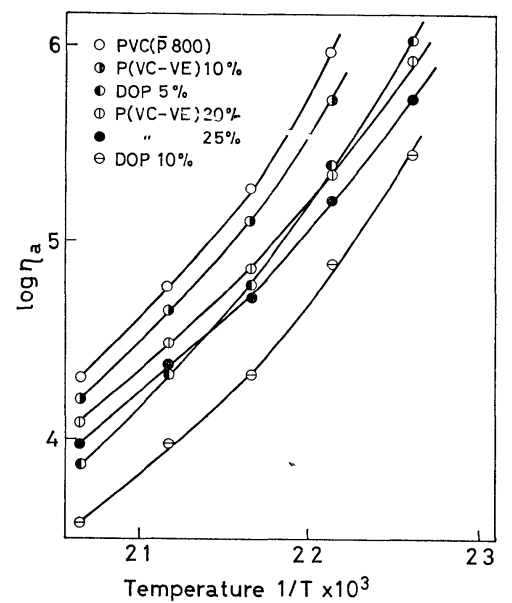

F1g. 3. Temperature dependence of $\eta_{a}$ of blends and plasticized PVC.

\section{$3 \cdot 4$ PVC と $\mathrm{PVC}+\mathrm{P}(\mathrm{VC}-\mathrm{VE})$ の流動性}

DVC $\bar{p} 800$ と $\mathrm{PVC}(\bar{p} 800)+25 \% \mathrm{P}(\mathrm{VC}-\mathrm{VE})$ の 両樹脂について寸法の異なる 5 種のノズルを用いて， 各圧力下で得られたQから $\tau_{\omega}^{\prime}$ と $D_{\omega}^{\prime}$ との関係を求 めた. Fig. 4, 5 は $L / R$ が $5 \sim 20$ の範囲で $190^{\circ} \mathrm{C}$ 牞いて求めた流動曲線を示したもので，L/Rが大きく なるにつれ曲線は $\tau_{\omega}^{\prime}$ の小さい方へ寄っている. 同一 のせん断速度を与える $P$ と $L / R$ との関係から，常 法により管長補正を施した曲線を Fig. 4 扣よび 5 亿点

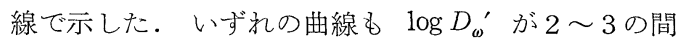
( PVC の場合は 2.3, PVC+P(VC-VE) の場合 2.4) に屈曲点をもち，この点以上では押出物が脈動するこ とが観察される。

$$
4 \text { 考察 }
$$

PVC 飞 P (VC-VE) を添加した混合樹脂組成物は, DOP を添加した PVC あるいは PVC 単独とは異な り, 見かけ溶融粘度の温度依存性が少なく, また流動 


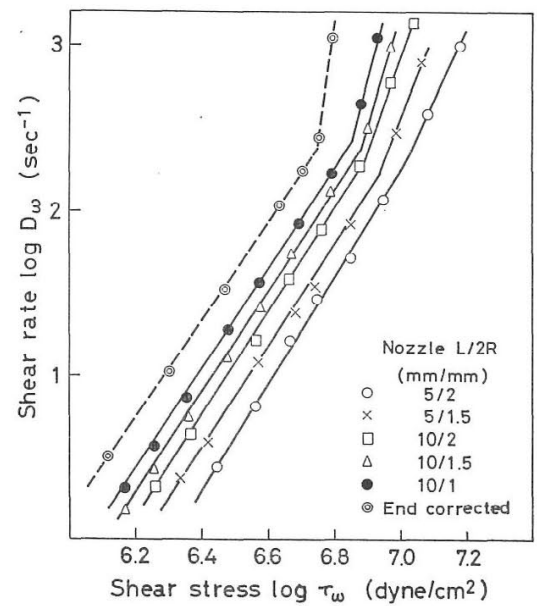

Fig. 4. Flow curve for PVC having $\bar{p}=800$.

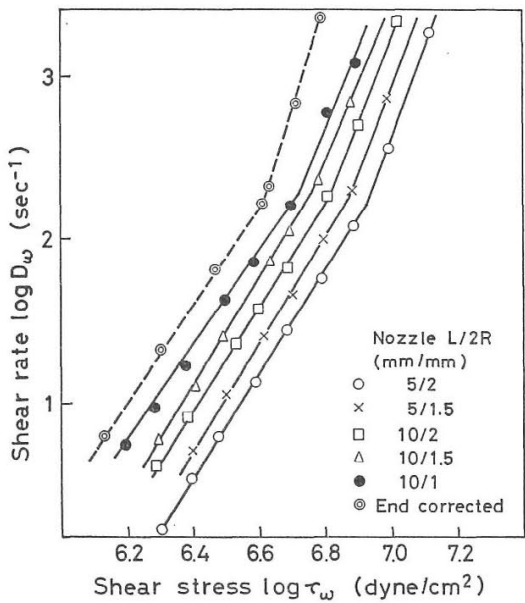

Fig. 5. Flow curves for the blend of $75 \%$ PVC $\overline{(p} 800)$ and $25 \% \mathrm{P}(\mathrm{VC}-\mathrm{VE})$.

の活性化ニネルギは，一定量の $\mathrm{P}(\mathrm{VC}-\mathrm{VE})$ を添加す れば変化しないことがわかった。これは，Fig. 1 か らるわかるよ $\mathrm{P}(\mathrm{VC}-\mathrm{VE})$ が混在することによって PVC の流動を 助けている現象之定性的に考光られるので, P(VCVE）が PVC中にぞのよらな形態で存在するかにつ いて考察した。懸濁重合粒子の形態をとる PVC 扣よ び P (VC-VE) の粉末の混合物が熱混練をうけて溶出 する過程と最終形態とが考察の対象となる。

\section{4. $1 \mathrm{PVC}+\mathrm{P}(\mathrm{VC}-\mathbf{V E})$ 混合組成物の加工成型物 の顕微鏡観察}

190ㄷ K晾方るフーテストの流出物の横断面を顕 微鏡で钼察すると Fig. 6 の写真のようになり， PVC

(上网) ほ均質構造をとっているのに反し， $\mathrm{PVC}+\mathrm{P}$ (VC-VE) 25\%混合物（下図）は不均質な内部構造を もっている。これは流動率の高い $\mathrm{P}(\mathrm{VC}-\mathrm{VE})$ と流動
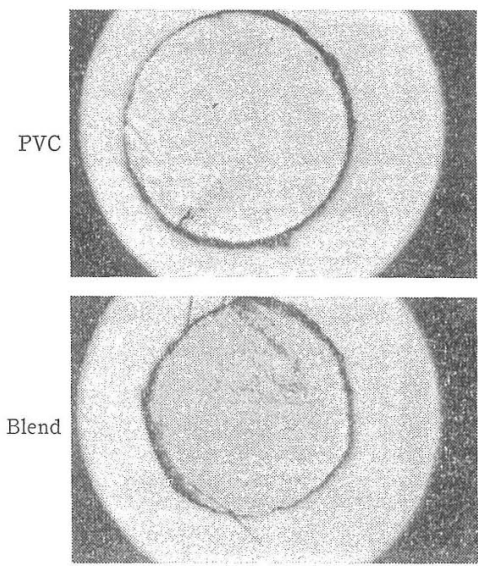

Fig. 6. Microscopic observation of cross section of the flow test specimens.
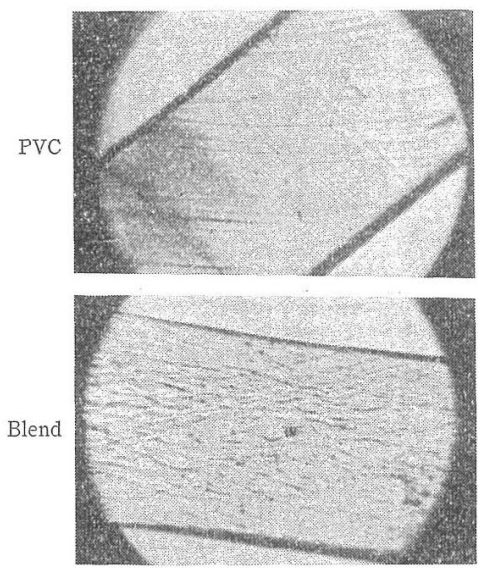

Fig. 7. Microscopic observation of cross section of the fabricated sheets.

率の低いPVC とが完全相溶の形態をとらずに流出し たためと考えられる。同様にFig. 7 はそれぞれの樹脂 をベースとして安定剤，滑剂を加充工業用押出機で厚 さ $1 \mathrm{~mm}$ のシートを製造し，只の断面を観察した結果 である。この場合，流出温度は $210^{\circ} \mathrm{C}$ に達し，樹脂は スクリュー内で混練されているが，PVC+P $(V C-V E)$ のシートはやはり不均質構造をとっていることが認め られる。なお，成分樹脂の懸濁重合粒子はいずれも直 径約 $100 \mu$ であるが，これらの写真によれば，混練に より相当均質化されているが，完全には相溶していな いことがわかる。

\section{$4 \cdot 2$ 粘弾性吸收による分散状態の検討}

$P V C+P(V C-V E)$ 混合樹脂の加工物中の $\mathrm{P}(\mathrm{VC}-$ VE）の存在状態をみるため，强制振動法に上って損 失弾性率 $E^{\prime \prime}$ を測定した。すなおら， $\operatorname{PVC}(\bar{p} 800)$ に $\mathrm{P}(\mathrm{VC}-\mathrm{VE})$ を 5 および $25 \%$ 添加した混合物と各成分 の $E^{\prime \prime}$ を一定周波数 110 サイクルで温度を变光て測定 した、試料はフローテスト用に混練したシートを 190 


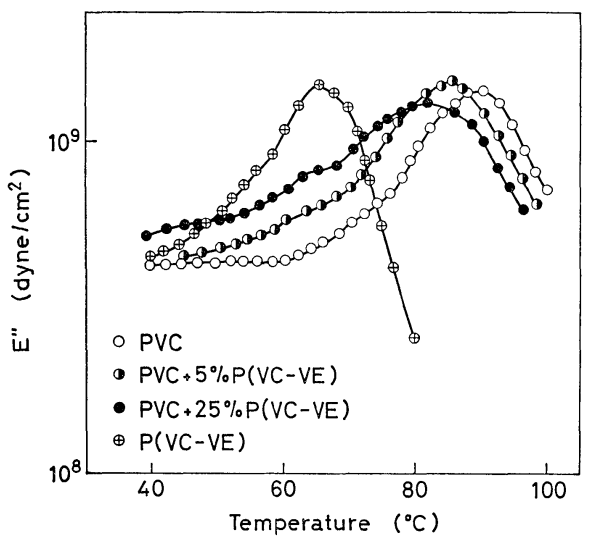

Fig 8. Temperature dependence of the dynamic loss modulus for the blends and the components.

${ }^{\circ} \mathrm{C}$ ，プレス圧 $150 \mathrm{~kg} / \mathrm{cm}^{2}$ で 3 分間プレス成型したも のである. Fig. 8 は上記 5 種の樹脂の $E^{\prime \prime}$ の温度依存 性をそれぞれ示したるのである。単独の PVC および $\mathrm{P}(\mathrm{VC}-\mathrm{VE})$ はそれ先れの転移点に相当する温度に $E^{\prime \prime}$ のピークを示して打り，P(VC-VE) と PVC との混 合物の $E^{\prime \prime}$ 曲線はいずれも $90^{\circ} \mathrm{C}$ 以下で幅が広がると 同時に, $\mathrm{P}(\mathrm{VC}-\mathrm{VE})$ のピークに相当する $65^{\circ} \mathrm{C}$ の点に ショルダーを示している。一般に二成分混合系に拮い て両成分が相溶性よく混合した場合はガラス転移領域 飞抢汸る分散は一つとなり，相溶性のない場合は成分 の二つの分散が起こる．Fig. 8 亿示した混合組成物に おいては PVC の分散がやや低温側飞移って分散が広 くなって沶り，一方 $\mathrm{P}(\mathrm{VC}-\mathrm{VE})$ の分散がわずか残 っている。このことは $\mathrm{PVC}+\mathrm{P}(\mathrm{VC}-\mathrm{VE}) 25 \%$ よ成 る成型物中には, $[\mathrm{PVC}+\mathrm{P}(\mathrm{VC}-\mathrm{VE})]$ の相溶系の注 か飞 $\mathrm{P}(\mathrm{VC}-\mathrm{VE})$ の単独系が存在することを示唆し， 混合樹脂粉末の溶融混練の過程では, 樹脂は次のよう な形態をとっているものと考兄られる。

$\begin{array}{ll}\text { 混合樹脂粉末 } & \text { 加工後 } \\ \mathrm{PVC} & (1) \\ \mathrm{P}(\mathrm{VC}-\mathrm{VE}) & (2) \\ \text { 〔PVC+P(VC-VE) }) & (3) \\ \mathrm{P}(\mathrm{VC}-\mathrm{VE}) & (4)\end{array}$

すなわち，混合樹脂粉末に和ける(2)の含有率が一定 値を越えると, 混練加工後は(4)の中に(3)が分散して存 在するモデルが考兄られ，(2)の含有率が一定值以下の ときには加工中は(3)の濃度が大きく，一部には(3)の流 動単位が接触して流動するものと考えられる．P(VC-
VE）濃度が20\%以上で混合物の流動の 活性化ェネル ギが注涪一定值を示すのは，(3)の表面が均質汇(4)でぬ らされていると解釈されよう。

\section{5 結 論}

以上, $P V C+P(V C-V E)$ 混合組成物の流動性を, PVC 単独重合物, 可塑化 PVC 扝上び他の硬質 PVC 材料と比較してフローテスターで実験した結果につい て述べた。

$\mathrm{PVC}+\mathrm{P}(\mathrm{VC}-\mathrm{VE})$ の溶融粘度は高温側では PVC および外部可塑化物の溶融粘度と同等であるが，低温 側では低くなる傾向を示した。PVCの見かけの流動 活性化ェネルギは $\mathrm{P}(\mathrm{VC}-\mathrm{VE})$ の添加によって低下す るが，添加量が20\%以上になると注涪同じ值を示し， 一般の可塑剤とは異なる挙動を与光た。 $\mathrm{P}(\mathrm{VC}-\mathrm{VE})$ をPVC に添加したときの特異な流動挙動を解明する ため，成型品の顕微鏡観察拈よび動的分散の測定を行 なった結果，成型品は PVC と P (VC-VE) とが完全 に相溶した系をつくらず，一部相溶している〔PVC $+\mathrm{P}(\mathrm{VC}-\mathrm{VE})]$ の流動単位の表面を $\mathrm{P}(\mathrm{VC}-\mathrm{VE})$ が 㫟呿っているような構造をるっていると考光られた。 低い温度域で溶融粘度が低いことは, 最終の流出工程 まで，流動単位表面を奴している $\mathrm{P}(\mathrm{VC}-\mathrm{VE})$ が 寄与しているもの之考光た。硬質 PVC が易加工性 でなければならないために，原料のPVC平均重合度 は一般に 700 から 600 にまで至っているが，最終的な 流出温度に抢ける流動性とともに，流出温度に達する までの低い温度に和ける流動性を含めて考察すること が実際の加工操作に执いて必須である。このような点 を考慮すれば，本研究に用いた混合樹脂は加工性に特 異な寄与を与えるものであることが期待されよう．

\section{参 考 文 献}

1）星勇二，小野塚満男，特公 $36-22733$

2）同上特公 $37-12126$

3）同上 USP 3.168594

4）同上 $\mathrm{BP} 928799$

5）同 上 FP 1267595

6) Schildknecht, G. E., "Vinyl and Related Polymers", Chap. 7 (1959), John Wsley \& Son, New York

7) Bagley, E. B., J. Appl. Phys., 28, 624 (1957).

8）松本勝周, 吉川真价, 工化，63，80（1960）

9）深沢義朗，工化，63，459（1960). 